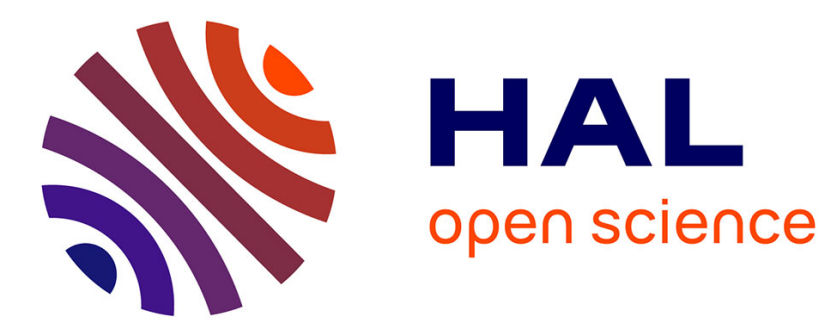

\title{
Sputter-Deposited Amorphous LiCuPO 4 Thin Film as Cathode Material for Li-ion Microbatteries
}

\author{
Vinsensia Ade Sugiawati, Florence Vacandio, Philippe Knauth, Thierry
}

Djenizian

\section{- To cite this version:}

Vinsensia Ade Sugiawati, Florence Vacandio, Philippe Knauth, Thierry Djenizian. Sputter-Deposited Amorphous LiCuPO 4 Thin Film as Cathode Material for Li-ion Microbatteries. ChemistrySelect, 2018, 3 (2), pp.405-409. 10.1002/slct.201702429 . hal-02656702

\section{HAL Id: hal-02656702 \\ https://hal-amu.archives-ouvertes.fr/hal-02656702}

Submitted on 5 Jun 2020

HAL is a multi-disciplinary open access archive for the deposit and dissemination of scientific research documents, whether they are published or not. The documents may come from teaching and research institutions in France or abroad, or from public or private research centers.
L'archive ouverte pluridisciplinaire HAL, est destinée au dépôt et à la diffusion de documents scientifiques de niveau recherche, publiés ou non, émanant des établissements d'enseignement et de recherche français ou étrangers, des laboratoires publics ou privés. 


\title{
Sputter-Deposited Amorphous $\mathrm{LiCuPO}_{4}$ Thin Film as Cathode Material for Li-ion Microbatteries
}

\author{
Vinsensia Ade Sugiawati, ${ }^{[a]}$ Florence Vacandio, ${ }^{[a]}$ Philippe Knauth ${ }^{[a]}$ and Thierry Djenizian* ${ }^{* b]}$
}

\begin{abstract}
We report the electrochemical performance of amorphous $\mathrm{LiCuPO}_{4}$ thin films obtained by radio frequency sputtering as a cathode material for Li-ion microbatteries. The thin films were characterized by X-ray diffraction, scanning electron microscopy, profilometry and electrochemical techniques. Charge/ discharge profiles and cycling performance were evaluated in lithium electrochemical test cells. Cyclic voltammogram of the $\mathrm{LiCuPO}_{4}$ film shows the typical redox reaction peak at $\sim 1.9 \mathrm{~V}$ vs. $\mathrm{Li} / \mathrm{Li}^{+}$. A discharge capacity of $160 \mathrm{mAhg}^{-1}\left(50 \mu \mathrm{Ahcm} \mathrm{cm}^{-2}\right)$ is attained for the first cycle at $\mathrm{C} / 10$ to reach a stable capacity of $70 \mathrm{mAhg}^{-1}\left(22 \mu \mathrm{Ah \textrm {cm } ^ { - 2 }}\right)$ with good stability over 160 cycles. For comparison, the electrochemical performance of a crystalline $\mathrm{LiCuPO}_{4}$ film was investigated. The first discharge could deliver a high capacity of around $375 \mathrm{mAh} \mathrm{g}^{-1}$ at $\mathrm{C} / 10$, but the capacity decayed quickly to a low capacity of $11 \mathrm{mAhg}^{-1}$ over 50 cycles. The results show that the $\mathrm{LiCuPO}_{4}$ amorphous materials can be considered as the exciting cathode candidate for Li-ion microbatteries.
\end{abstract}

\section{Introduction}

In recent years, Li-ion batteries have received great attention for a variety of energy storage devices due to their attractive performance including high specific energy, power density and thermal stability. ${ }^{[1]}$ Much effort has been devoted to improving the electrochemical performance of Li-ion batteries, leading to the discovery of novel cathode materials with many improvements in terms of safety, cycle life, power and energy densities to fulfill the demands for different energy storage applications. In particular, cathode materials based on lithium transition metal phosphates $\mathrm{LiMPO}_{4}(\mathrm{M}=\mathrm{Fe}, \mathrm{Co}, \mathrm{Ni}, \mathrm{Mn})$ have attracted much attention due to their excellent cycling behavior and rate capability. ${ }^{[2]}$

[a] V. A. Sugiawati, Dr. F. Vacandio, Prof. P. Knauth Department of Chemistry CNRS, MADIREL Laboratory, UMR 7246Aix-Marseille Université 13397 Marseille, France

[b] Prof. T. Djenizian IMT Mines Saint-Etienne Center of Microelectronics in Provence Department of Flexible Electronics F - 13541 Gardanne, France

E-mail: thierry.djenizian@mines-stetienne.fr
Researchers have reported several strategies to enhance the performance of cathode materials. For instance, Zhang et al. $^{[3]}$ synthesized a mesoporous biocarbon nanowire coated $\mathrm{LiFePO}_{4}$ with high-energy quantum dots by using a highenergy biomolecule ATP in order to improving the electrochemical performance of Li-ion batteries; this nanostructured $\mathrm{LiFePO}_{4}$ displayed a high discharge capacity of $197 \mathrm{mAhg}^{-1}$ at the $\mathrm{C} / 10$ rate, which is higher than the theoretical specific capacity of $\mathrm{LiFePO}_{4}\left(170 \mathrm{mAhg}^{-1}\right)$. Also, Nagaraju et al. ${ }^{[4]}$ fabricated thin sheets of reduced graphene oxide ( $r G O)$ wrapped $\mathrm{LiFePO}_{4}$ composite using a co-precipitation method which shows an enhanced performance compared with the bulk $\mathrm{LiFePO}_{4}$. More recently, electrodes composed of $\mathrm{Cu}$ have been investigated as cathode materials for Li-ion batteries such as $\mathrm{Cu}_{3}\left(\mathrm{PO}_{4}\right)_{2}{ }^{[5]} \quad \mathrm{Li}_{3-\mathrm{x}} \mathrm{Cu}_{\mathrm{x}} \mathrm{PO}_{4}{ }^{[6]} \quad \mathrm{LiCuPO}_{4}{ }^{[7]}$ etc. Besides good theoretical gravimetric capacity, low cost, and being environmentally benign, the potentials of $\mathrm{Cu}^{0} / \mathrm{Cu}^{1+} / \mathrm{Cu}^{2+}$ redox couples are compatible with the stability domain of classical electrolytes. ${ }^{[8]}$ However, the performance of thin film cathodes still needs to be improved to realize high performance Li-ion microbatteries. So far, $\mathrm{LiCuPO}_{4}$ (LCP) material prepared by a solid state reaction method involving a stochiometric mixture of $\mathrm{Li}_{2} \mathrm{CO}_{3}, \mathrm{CuO}$, and $\left(\mathrm{NH}_{4}\right)_{2} \mathrm{HPO}_{4}$ has been reported as a cathode for Li-ion batteries. The LCP cathode has been considered as a promising cathode candidate due to its ability to intercalate more than one $\mathrm{Li}$ atom per active transition metal, leading to a high theoretical capacity $\left(>300 \mathrm{mAhg}^{-1}\right){ }^{[7]}$ Since this has been the only study on $\mathrm{LiCuPO}_{4}$ composite electrodes reported to date, further investigation on thin film cathodes is needed to verify their performance. In order to obtain high performance thin film cathodes, numerous studies on the fabrication of thin films using a variety of processing methods such as radiofrequency (r.f.) sputtering, ${ }^{[9]}$ chemical vapor deposition, ${ }^{[10]}$ pulsed laser deposition (PLD), ${ }^{[11]}$ and sol-ge ${ }^{[12]}$ have been reported. Among them, r.f. sputtering shows many advantages such as better surface adhesion, smaller grain size, good control of film thickness, film uniformity and low-temperature plasma production. ${ }^{[13]}$ Moreover, it has been widely utilized to fabricate electrode components for all-solid-state Li-ion microbatteries owing to its excellent cyclability with almost no capacity loss. ${ }^{[14]}$

In this work, we report for the first time the remarkable electrochemical properties of an amorphous LCP thin film deposited by radio frequency (r.f.) sputtering. We show that amorphous LCP layers reveal a good capacity over 160 cycles. Interestingly, the performance of the amorphous LCP film is higher than that of crystalline LCP slurries carrying binder and additives. 


\section{Results and Discussion}

LCP thin films were prepared using r.f. sputtering technique. As can be seen in the Figure S1 (see Supporting Information), a gaseous plasma is generated by applying an electric field inside a vacuum chamber filled with an inert gas such as Argon at a specific pressure. The positively charged ions $\left(\mathrm{Ar}^{+}\right)$are accelerated into the negatively charged LCP target material, leading to the the atoms ejection. Then, the atoms are diffused and deposited as a LCP thin film on the surface of the Ti foil. ${ }^{[15]}$

Furthermore, Thornton developed a structure-zone model to prove the film morphology evolution upon sputtering with different argon pressure and homologous substrate temperature $(T / T m$, where $T$ is the substrate temperature, $T m$ is the melting temperature of the target). In the present experiment, we carried out the deposition process at room temperature with an argon pressure of 10 mTorr, meaning that LCP deposition is in zone 1 structures $(\mathrm{T} / \mathrm{Tm}=\sim 0.1-0.5)$ which is amorphous and it is difficult to identify the columnar growth for certain materials, as reported previously. ${ }^{[16]}$

Prior to battery assembly, the structural properties of the different LCP electrodes were studied by XRD (Figure 1a). The

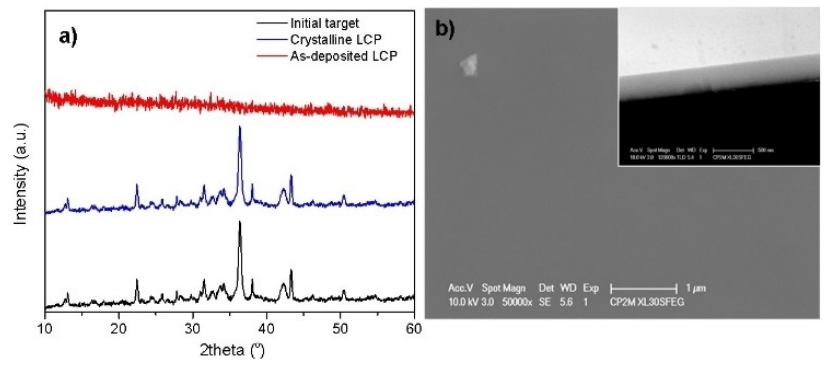

Figure 1. XRD patterns of the initial target, crystalline LCP film and asdeposited LCP film (a). Corresponding SEM images (b) of as-deposited LCP film from the top view and cross-sectional view (inset in Figure 1b).

initial target and the slurry obtained from a crystalline powder show the same peaks corresponding to well-crystallized LCP phases. According to work conducted by Amine, ${ }^{[7]}$ LCP material has orthorhombic symmetry with the following unit cell parameters : $a=5.31 \AA, b=13.43 \AA$, and $c=4.91 \AA$. It has been reported that the structure of $L C P$ is different from other olivine materials due to a much larger unit cell compared to the olivine $\mathrm{LiMPO}_{4}(\mathrm{M}=\mathrm{Co}, \mathrm{Fe}, \mathrm{Ni}$, and $\mathrm{Mn})$. For comparison, after deposition at room temperature, the XRD pattern of the asdeposited LCP thin film has no visible diffraction peak indicating that the film is amorphous. This phenomenon may be due to the deposition being performed at room temperature, which cannot provide enough energy to cause the recrystallization of the sputtered particles. This result is in agreement with previous work, reporting that crystalline phases with a regular atomic arrangement can be obtained by either substrate heating during the deposition process or a post-annealing treatment at high temperature. ${ }^{[9,17]}$ However such a heating treatment step of the thin films is not compatible with the polymer electrolytes and low-temperature substrate materials. ${ }^{[18]}$ In addition, it will add complexity to the battery preparation process and also cause unwanted side reactions between the deposited film and the electrolyte, limiting the application of Li-ion microbatteries. Hence, lowtemperature processing of the thin film cathodes are favored to fabricate the microbatteries. ${ }^{[18,19]}$

SEM images of the as-deposited LCP thin film obtained after 3 hours on a Si substrate are given in Figure $1 \mathrm{~b}$. The morphology observed from the top and cross sectional views (inset in Figure 1b) reveal that the layer is uniform and dense with a thickness of $850 \mathrm{~nm}$ measured by profilometry.

The cyclic voltammogram of the amorphous LCP film has been recorded to elucidate the electrochemical reactions undergone during cycling (Figure 2a). The cyclic voltammogram obtained at a scan rate of $0.5 \mathrm{mV} / \mathrm{s}$ exhibits a broad reduction peak in the voltage range between $1.7 \mathrm{~V}$ and $2.3 \mathrm{~V}$ vs. $\mathrm{Li} / \mathrm{Li}^{+}$. It can be assigned to the insertion of $\mathrm{Li}^{+}$ions into the LCP structure and the typical peak for amorphous compounds. In addition, a broad oxidation peak marked by an increment of the current density is observed in the voltage range between 1.4 and $3.4 \mathrm{~V}$ vs. $\mathrm{Li} / \mathrm{Li}^{+}$suggesting that $\mathrm{Li}^{+}$ions also reacted with other phases meaning a different conversion reaction may occur.

Other reduction peaks with high current densities can be also observed at a potential of around $1.2 \mathrm{~V} \mathrm{vs.} \mathrm{Li} / \mathrm{Li}^{+}$, corresponding to $\mathrm{Li}_{3} \mathrm{PO}_{4}$ phases formation during the discharge process. ${ }^{[20]}$ The electrochemical conversion reactions of the LCP cathode may be written as the following Equations $(1-4):[5,7,21]$

$$
\begin{aligned}
& \mathrm{LiCuPO}_{4}+2 \mathrm{Li}^{+}+2 \mathrm{e}^{-} \rightarrow \mathrm{Li}_{3} \mathrm{PO}_{4}+\mathrm{Cu} \rightleftharpoons \\
& \mathrm{LiCuPO}_{4}+2 \mathrm{Li}^{+}+2 \mathrm{e}^{-} \\
& \mathrm{LiCuPO}_{4}+2 \mathrm{Li}^{+}+2 \mathrm{e}^{-} \rightleftharpoons \mathrm{Li}_{3} \mathrm{PO}_{4}+\mathrm{Cu} \\
& \mathrm{Li}_{x} \mathrm{Cu}(\mathrm{I})_{\mathrm{y}} \mathrm{PO}_{4}+\mathrm{Li}^{+}+\mathrm{e}^{-} \rightleftharpoons \mathrm{Li}_{3} \mathrm{PO}_{4}+\mathrm{Cu} \\
& \mathrm{Li}_{x} \mathrm{Cu}(\mathrm{II})_{y} \mathrm{PO}_{4}+\mathrm{Li}^{+}+\mathrm{e}^{-} \rightleftharpoons \mathrm{Li}_{3} \mathrm{PO}_{4}+\mathrm{Cu}
\end{aligned}
$$

According to the Equation (1), the $\mathrm{LiCuPO}_{4}$ phase is electrochemically reduced to form a nanocomposite consisting of lithium rich (i.e., $\mathrm{Li}_{3} \mathrm{PO}_{4}$ ) and $\mathrm{Cu}$ during the discharge process. An irreversible conversion reaction at the first cycle probably takes place as previously reported. ${ }^{[22]}$ However, the reversible reaction occurs after the first cycle which results in smaller particle sizes compared to the initial LCP particles. Due to the fact that the oxidation state of copper in LCP is +2 , it can be deduced that the $\mathrm{Cu}^{+}$may be formed during cycling and the conversion reaction of $\mathrm{LCP}, \mathrm{Li}_{x} \mathrm{Cu}(\mathrm{I})_{y} \mathrm{PO}_{4}$, and $\mathrm{Li} x \mathrm{Cu}(\mathrm{II})_{y}$ $\mathrm{PO}_{4}$ into $\mathrm{Cu}$ and $\mathrm{Li}_{3} \mathrm{PO}_{4}$ could have occurred as given in Equation (2-4). Simply, the electrochemical conversion reactions of the LCP cathode could be described through the reduction of $\mathrm{Cu}^{2+}$ to intermediate of $\mathrm{Cu}^{+}$with one $\mathrm{Li}^{+}$insertion and then further reduction of $\mathrm{Cu}^{+}$to metallic $\mathrm{Cu}$ with another $\mathrm{Li}^{+}$insertion, and vice versa, totally delivering 2-electrons redox capacity. ${ }^{[23]}$ 

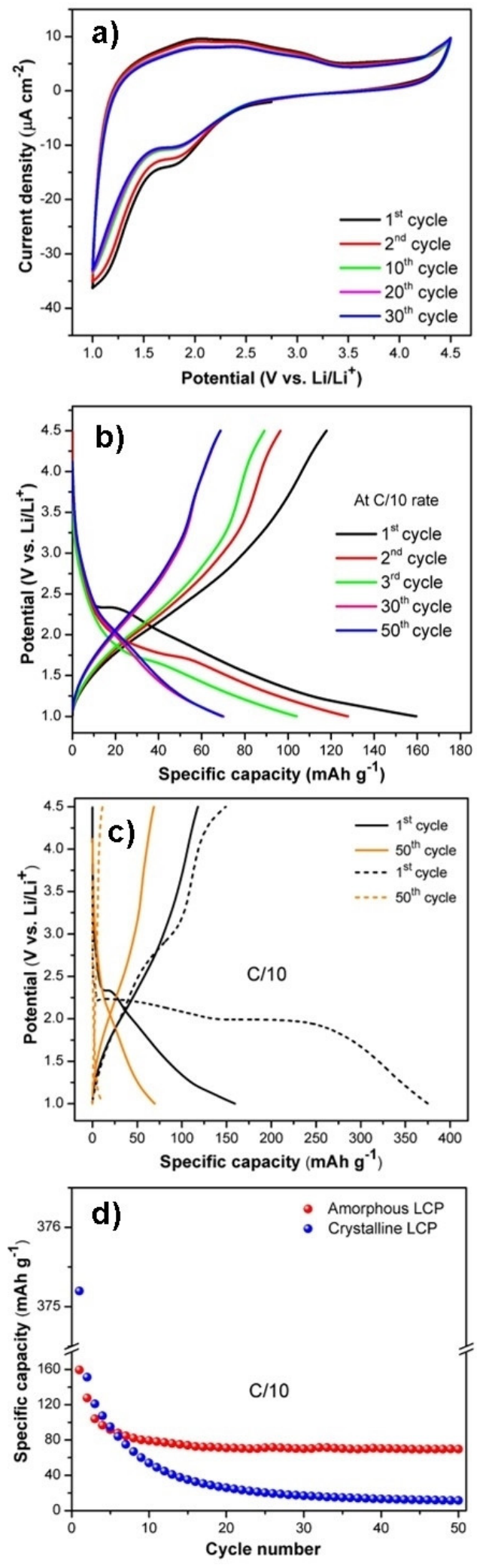

Figure 2. (a) Cyclic voltammograms of the as-deposited LCP film at a scan rate of $0.5 \mathrm{mV} / \mathrm{s}$ and (b) Typical galvanostatic charge/discharge profiles. (c) Charge/discharge profiles of ( $\mathbf{m a}$ ) crystalline LCP film and (-) amorphous LCP film and (d) discharge capacity of the amorphous and crystalline LCP films at $\mathrm{C} / 10$.
The electrochemical behavior was then studied by galvanostatic cycling experiments. The charge/discharge profiles for the amorphous LCP thin film at C/10 can be seen in Figure $2 b$. The film exhibits one pseudoplateau at around $2.3 \mathrm{~V}$ vs. $\mathrm{Li}^{\prime} / \mathrm{Li}^{+}$ in the $1^{\text {st }}$ cycle and two pseudoplateaus at around $1.8 \mathrm{~V} \mathrm{vs.} \mathrm{Li} /$ $\mathrm{Li}^{+}$in the $2^{\text {nd }}$ and $3^{\text {rd }}$ cycles, which is in good correlation with the cyclic voltammogram of the amorphous LCP film.

The galvanostatic charge/discharge profiles obtained at C/ 10 of the half-cell battery show a first charge capacity of the amorphous LCP film of $118 \mathrm{mAhg}^{-1}\left(37 \mu \mathrm{Ah \textrm {cm } ^ { - 2 } )}\right.$ and a discharge capacity of $160 \mathrm{mAhg}^{-1}\left(50 \mu \mathrm{Ahcm}^{-2}\right)$ leading to a coulombic efficiency of $74 \%$ (the corresponding $\mathrm{Li}^{+}$ions insertion for the charge and discharge capacities are $0.7 \mathrm{~mol}$ and $1 \mathrm{~mol} \mathrm{Li}^{+}$ion per formula unit, respectively). The discharge capacities for the $2^{\text {nd }}, 3^{\text {rd }}, 30^{\text {th }}$, and $50^{\text {th }}$ cycles are $128 \mathrm{mAh} \mathrm{g}^{-1}$ $\left(50 \mu \mathrm{Ah} \mathrm{cm}^{-2}\right), \quad 104 \mathrm{mAhg}^{-1} \quad\left(33 \mu \mathrm{Ah} \mathrm{cm}{ }^{-2}\right), \quad 70 \mathrm{mAh} \mathrm{g}^{-1}$ $\left(22 \mu \mathrm{Ahcm}^{-2}\right)$ and $70 \mathrm{mAh} \mathrm{g}^{-1}\left(22 \mu \mathrm{Ahcm}^{-2}\right)$, respectively. The coulombic efficiency continuously increases from $76 \%$ to almost $100 \%$. Moreover, it can be pointed out that the discharge curves overlapped together very well for the $30^{\text {th }}$ and $50^{\text {th }}$ cycles with a good capacity of $70 \mathrm{mAhg}^{-1}\left(22 \mu \mathrm{Ahcm}^{-2}\right)$, implying a good reversibility and stability of $\mathrm{Li}^{+}$ion insertion and extraction after the first few cycles.

For comparison, we also observed a crystalline LCP film prepared by mixing LCP powder with a binder and conductive agent. A SEM image of the crystalline LCP film is shown in Figure S2 (see Supporting Information). The charge/discharge profiles of amorphous and crystalline films can be seen in Figure 2c. A large discharge plateau observed for the crytalline LCP film at $1.9 \mathrm{~V}$ vs. $\mathrm{Li}^{2} \mathrm{Li}^{+}$at the first cycle and a charge pseudoplateau at around $2.7 \mathrm{~V}$ vs. $\mathrm{Li} / \mathrm{Li}^{+}$correspond to the insertion/extraction of $\mathrm{Li}^{+}$ions and also conversion/deconversion reactions of $\mathrm{Cu}^{0} / \mathrm{Cu}^{1+} / \mathrm{Cu}^{2+}$ redox couples. Figure $2 \mathrm{~d}$ shows the capacity of the crystalline LCP film decreases rapidly up to a very low capacity, delivering a capacity of $11 \mathrm{mAh} \mathrm{g}^{-1}$. This result is in good agreement with previous work reported by Zhong et al. ${ }^{[5]}$ showing that almost no cycle performance of the as-prepared crystalline cathode could be observed due to the fact that the reversibility of the electrode is very sensitive to the particle size. Interestingly, herein, the amorphous LCP film shows better performance than the crystalline LCP film, preserving a good capacity over 50 cycles.

In light of these results, the electrochemical performance of amorphous LCP film compared to crystalline LCP film is shown in Table 1.

\begin{tabular}{|c|c|c|c|c|}
\hline LCP & $\begin{array}{l}1^{\text {st }} \text { cycle rever- } \\
\text { sible } \\
\text { capacity } \\
\left(\mathrm{mAh} \mathrm{g}^{-1}\right)\end{array}$ & $\begin{array}{l}\text { Irreversible } \\
\text { capacity } \\
\left(\mathrm{mAh} \mathrm{g}{ }^{-1}\right)\end{array}$ & 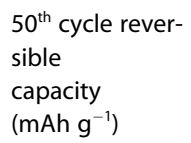 & $\begin{array}{l}\text { Cycling } \\
\text { efficiency } \\
\text { (\%) }\end{array}$ \\
\hline Amorphous & 128 & 31 & 70 & 55 \\
\hline Crystalline & 151 & 224 & 11 & 7 \\
\hline
\end{tabular}


When both amorphous LCP film and crystalline LCP film are cycled between 1 and $4.5 \mathrm{~V}$ vs. $\mathrm{Li} / \mathrm{Li}^{+}$, amorphous LCP film shows improved performance compared to crystalline LCP film. For amorphous film, a discharge capacity of $70 \mathrm{mAh} \mathrm{g}^{-1}$ was obtained after 50 cycles, corresponding to $55 \%$ cycling efficiency considering the $1^{\text {st }}$ cycle reversible capacity, while for the crystalline film, the first discharge delivers a high capacity around $375 \mathrm{mAhg}^{-1}$ at C/10 with a low cycling efficiency of about $7 \%$ and a very high irreversible capacity of $224 \mathrm{mAh} \mathrm{g}^{-1}$. A high irreversible capacity loss observed at the first cycle may be associated with an inhomogeneous carbon distribution in crystalline LCP film and its large particles, leading to the difficulty in $\mathrm{Li}^{+}$diffusion. The better cycling performance of the amorphous sample may be due to the smaller sputtered particle of discharge products (i.e., $\mathrm{Cu}$ and $\mathrm{Li}_{3} \mathrm{PO}_{4}$ ) in the amorphous sample, providing better physical contact among them which may facilitate the recharge reaction and improve the electrochemical cycling performance of the LCP cathode. ${ }^{[5]}$

The cycling performance of amorphous LCP film at different kinetics is illustrated in Figure 3. The battery delivers a stable

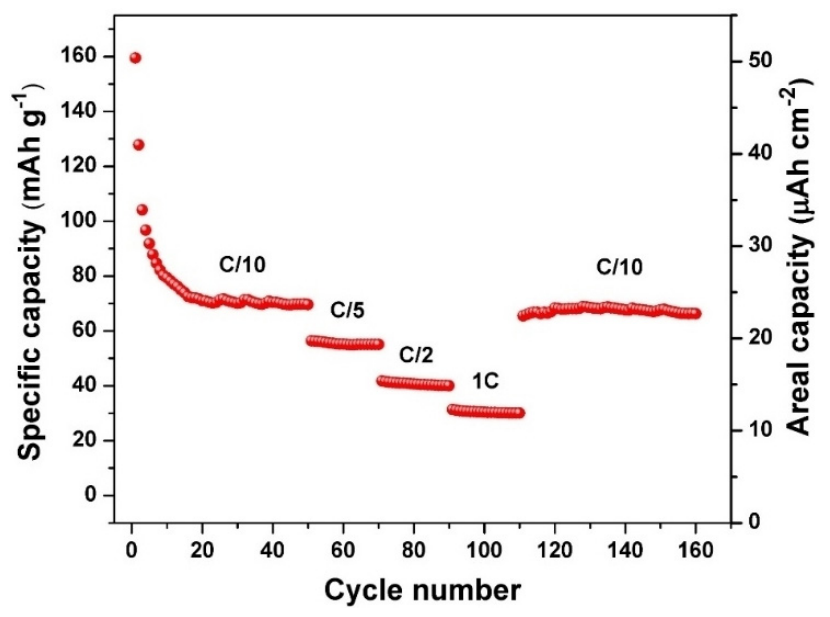

Figure 3. Discharge capacity of the amorphous LCP film at multi C-rates.

capacity of $70 \mathrm{mAhg}^{-1}\left(22 \mu \mathrm{Ahcm}^{-2}\right)$ at $\mathrm{C} / 10,55 \mathrm{mAhg}^{-1}$ $\left(17 \mu \mathrm{Ahcm}^{-2}\right)$ at $\mathrm{C} / 5,40 \mathrm{mAhg}^{-1}\left(13 \mu \mathrm{Ahcm}^{-2}\right)$ at $\mathrm{C} / 2$, and $30 \mathrm{~mA} \mathrm{~h} \mathrm{~g}{ }^{-1}\left(10 \mu \mathrm{Ahcm}^{-2}\right)$ at $1 \mathrm{C}$ beyond 110 cycles. The capacity can be recovered after cycling at fast C-rate with a discharge capacity of $70 \mathrm{~mA} \mathrm{~h} \mathrm{~g} \mathrm{~g}^{-1}\left(22 \mu \mathrm{Ahcm}^{-2}\right)$ over 160 cycles, revealing that the reversibility of the conversion reaction of thin films could be improved by sputtering. It is important to notice that reasons for the capacity fading for the initial cycles can be attributed to the loss of the active material. Indeed, dissolution of $\mathrm{Cu}$ into an electrolyte is supposed to form an intermediate $\mathrm{Cu}^{+}$compound leading to the increasingly ineffective reconversion process during recharging. ${ }^{[23,24]}$ Moreover, it is likely caused by the initial particle size of the LCP cathode and the insulating character of $\mathrm{Li}_{3} \mathrm{PO}_{4}$ which formed after the discharge process. ${ }^{[25]}$ The amorphous LCP film provides a good capacity suggesting that the amorphous component seems to be a potential cathode material for Li-ion microbatteries.

\section{Conclusion}

Amorphous $\mathrm{LiCuPO}_{4}$ thin films were deposited onto $\mathrm{Ti}$ foils by r.f. sputtering at room temperature. Charge/discharge cycling results show that the $\mathrm{LiCuPO}_{4}$ thin film has good electrochemical performance. The cyclic voltammogram of amorphous LCP film exhibits a broad reduction peak between 1.7 and $2.3 \mathrm{~V}$ vs. $\mathrm{Li}^{\mathrm{Li}} \mathrm{Li}^{+}$. A $850 \mathrm{~nm}$ thin film delivered a stable capacity of $70 \mathrm{mAh} \mathrm{g}^{-1}\left(22 \mu \mathrm{Ah} \mathrm{cm}^{-2}\right)$ at C/10 over 160 cycles with a high coulombic efficiency close to $100 \%$. For comparison, the electrochemical performance of a crystalline $\mathrm{LiCuPO}_{4}$ film has been studied. A first discharge could deliver a high capacity around $375 \mathrm{mAhg}^{-1}$ at C/10, but the capacity decayed quickly up to a very low capacity of $11 \mathrm{mAhg}^{-1}$ after 50 cycles. These results demonstrate that amorphous $\mathrm{LiCuPO}_{4}$ thin film deposited by r.f. sputtering could be considered as a cathode material for Li-ion microbatteries.

\section{Supporting Information Summary}

The experimental section can be found in the supporting information. The supporting Figures have been also provided.

\section{Acknowledgements}

We thank the région Provence Alpes Côte d'Azur for the financial support.

\section{Conflict of Interest}

The authors declare no conflict of interest.

Keywords: amorphous materials $\cdot \mathrm{LiCuPO}_{4} \cdot \mathrm{Li}$-ion microbatteries $\cdot$ radio frequency sputtering $\cdot$ thin films

[1] a) B. Dunn, H. Kamath, J.-M. Tarascon, Science 2011, 334, 928-935; b) B. Scrosati, J. Garche, J. Power Sources 2010, 195, 2419-2430.

[2] a) J. Liu, T. E. Conry, X. Song, L. Yang, M. M. Doeff, T. J. Richardson, J. Mater. Chem. 2011, 21, 9984-9987; b) D. Choi, D. Wang, I.-T. Bae, J. Xiao, Z. Nie, W. Wang, V. V. Viswanathan, Y. J. Lee, J.-G. Zhang, G. L. Graff, et al., Nano Lett. 2010, 10, 2799-2805; c) M. Yonemura, A. Yamada, Y. Takei, N. Sonoyama, R. Kanno, J. Electrochem. Soc. 2004, 151, A1352-A1356; d) X. Zhang, Y. Hou, W. He, G. Yang, J. Cui, S. Liu, X. Song, Z. Huang, Nanoscale 2015, 7, 3356-3372

[3] X. Zhang, Z. Bi, W. He, G. Yang, H. Liu, Y. Yue, Energy Environ. Sci. 2014, 7, 2285-2294.

[4] D. H. Nagaraju, M. Kuezma, G. S. Suresh, J. Mater. Sci. 2015, 50, 42444249.

[5] G. Zhong, J. Bai, P. N. Duchesne, M. J. McDonald, Q. Li, X. Hou, J. A. Tang, Y. Wang, W. Zhao, Z. Gong, P. Zhang, R. Fu, Y. Yang, Chem. Mater. 2015, 27, 5736-5744.

[6] K. Snyder, B. Raguž, W. Hoffbauer, R. Glaum, H. Ehrenberg, M. Herklotz, Z. Für Anorg. Allg. Chem. 2014, 640, 944-951.

[7] K. Amine, Active Material for Lithium Batteries, 2001, US6319632 B1.

[8] a) R. E. Ruther, H. Zhou, C. Dhital, K. Saravanan, A. K. Kercher, G. Chen, A. Huq, F. M. Delnick, J. Nanda, Chem. Mater. 2015, 27, 6746-6754; b) X. Shu-Yin, W. Xiao-Yan, L. Yun-Ming, H. Yong-Sheng, C. Li-Quan, Chin. Phys. B 2014, 23, 118202; c) C. W. Mason, F. Lange, K. Saravanan, F. Lin, D. 
Nordlund, ECS Electrochem. Lett. 2015, 4, A41-A44; d) G. Hautier, A. Jain S. P. Ong, B. Kang, C. Moore, R. Doe, G. Ceder, Chem. Mater. 2011, 23, 3495-3508.

[9] V. A. Sugiawati, F. Vacandio, M. Eyraud, P. Knauth, T. Djenizian, Nanoscale Res. Lett. 2016, 11, 365

[10] R. Zhang, X. Yang, Y. Gao, Y. Ju, H. Qiu, X. Meng, G. Chen, Y. Wei, Electrochimica Acta 2016, 188, 254-261.

[11] D. Fujimoto, N. Kuwata, Y. Matsuda, J. Kawamura, F. Kang, Thin Solid Films 2015, 579, 81-88.

[12] T. Kwon, T. Ohnishi, K. Mitsuishi, T. C. Ozawa, K. Takada, J. Power Sources 2015, 274, 417-423.

[13] a) Ş. Korkmaz, B. Geçici, S. D. Korkmaz, R. Mohammadigharehbagh, S Pat, S. Özen, V. Şenay, H. H. Yudar, Vacuum 2016, 131, 142-146; b) N. Evcimen Duygulu, A. O. Kodolbas, A. Ekerim, J. Cryst. Growth 2013, 381, 51-56; c) J.-W. Hoon, K.-Y. Chan, T.-Y. Tou, Ceram. Int. 2013, 39, S269S272.

[14] a) S. Komaba, N. Kumagai, M. Baba, F. Miura, N. Fujita, H. Groult, D. Devilliers, B. Kaplan, J. Appl. Electrochem. 2000, 30, 1179-1182; b) S Ferrari, M. Loveridge, S. D. Beattie, M. Jahn, R. J. Dashwood, R. Bhagat, J. Power Sources 2015, 286, 25-46; c) M. Létiche, M. Hallot, M. Huvé, T. Brousse, P. Roussel, C. Lethien, Chem. Mater. 2017, 29, 6044-6057; d) J. Trask, A. Anapolsky, B. Cardozo, E. Januar, K. Kumar, M. Miller, R. Brown, R. Bhardwaj, J. Power Sources 2017, 56-64; e) V. Dubois, B. Pecquenard, S. Soulé, H. Martinez, F. Le Cras, ACS Appl. Mater. Interfaces. 2017, 9, 2275-2284.

[15] M. S. Raven, J. Mater. Sci. Mater. Electron. 1994, 5, 129-146.

[16] a) J. A. Thornton, J. Vac. Sci. Technol. Vac. Surf. Films 1986, 4, 3059-3065; b) S. V. Ketov, R. Joksimovic, G. Xie, A. Trifonov, K. Kurihara, D. V. Louzguine-Luzgin, Heliyon 2017, 3.
[17] a) X.-J. Zhu, L.-B. Cheng, C.-G. Wang, Z.-P. Guo, P. Zhang, G.-D. Du, H.-K. Liu, J. Phys. Chem. C 2009, 113, 14518-14522; b) K.-F. Chiu, H.-Y. Tang, B.S. Lin, J. Electrochem. Soc. 2007, 154, A364-A368.

[18] J. Xie, N. Imanishi, T. Zhang, A. Hirano, Y. Takeda, O. Yamamoto, G. S. Cao, X. B. Zhao, Electrochimica Acta 2010, 55, 5440-5445.

[19] a) I. Quinzeni, S. Ferrari, E. Quartarone, D. Capsoni, M. Caputo, A. Goldoni, P. Mustarelli, M. Bini, J. Power Sources 2014, 266, 179-185; b) S. Lobe, C. Dellen, M. Finsterbusch, H.-G. Gehrke, D. Sebold, C.-L. Tsai, S. Uhlenbruck, O. Guillon, J. Power Sources 2016, 307, 684-689; c) S.-W. Jeon, J.-K. Lim, S.-H. Lim, S.-M. Lee, Electrochimica Acta 2005, 51, 268273.

[20] W. Zhao, G. Zhong, M. J. McDonald, Z. Gong, R. Liu, J. Bai, C. Yang, S. Li, W. Zhao, H. Wang, et al., Nano Energy 2016, 27, 420-429.

[21] L. Li, F. Meng, S. Jin, Nano Lett. 2012, 12, 6030-6037.

[22] S.-H. Yu, S. H. Lee, D. J. Lee, Y.-E. Sung, T. Hyeon, Small 2016, 12, 21462172.

[23] T. Li, Z. X. Chen, Y. L. Cao, X. P. Ai, H. X. Yang, Electrochimica Acta 2012, 68, 202-205.

[24] F. Wang, S.-W. Kim, D.-H. Seo, K. Kang, L. Wang, D. Su, J. J. Vajo, J. Wang, J. Graetz, Nat. Commun. 2015, 6, ncomms7668.

[25] C.-F. Sun, J. Hu, P. Wang, X.-Y. Cheng, S. B. Lee, Y. Wang, Nano Lett. 2016, $16,5875-5882$ 